\title{
An analysis of the correlation between profitability and liquidity of beverage companies in Chinese market
}

\begin{abstract}
Yuhan Zhang
Management School, University of Sheffield

Abstract

The relationship between profitability and liquidity is still controversial since many researchers obtain different conclusions from their studies. Besides, the Chinese market is getting more and more attention and profitability and liquidity are crucial for Chinese companies to keep operation management. Consequently, this thesis analyses the relationship between liquidity, company size, corporation growth and profitability of beverage companies in Chinese market between 2015 and 2017. Desk research can be used to getting the financial data published by the companies; the relationship was studied with the help of ratio analysis, horizontal analysis, description analysis, Pearson correlation coefficient and also a regression analysis. Surprisingly it was observed weak or insignificant positive correlation between liquidity, company size, corporation growth and profitability on the short run, contradicting the main literature. The conclusions are limited to the periods examined and the sample companies. Key words: Profitability, liquidity, Chinese beverage companies, Working capital, Current Ratio, Company Size and Corporation Growth
\end{abstract}

DOI: $10.7176 / \mathrm{RJFA} / 11-12-17$

Publication date:June 30th 2020

\subsection{Introduction}

\subsection{Background and main questions}

Wealth maximisation is a corporate goal which is virtually accepted by the whole world, with the exception of a few companies (Borad, 2018); therefore profitability is the primary concern for corporations, particularly internal users like managers and shareholders. Conversely, companies sometimes require vast capital in order to tackle financial issues. Liquidity is therefore regarded as an indicator in measuring a firm' $s$ ability to convert its assets to cash, for the sake of paying its immediate and short-term obligations (Averkamp, 2004). Differing sizes of companies will bring different operational performances for top executives; hence it is an important factor for decision making. By analysing corporation growth we can predict corporation's future development trends and development speed (Uyar, 2009). The relationship between profitability, liquidity, company size and corporation growth however, is still controversial since many researchers obtain different conclusions from their studies. Consequently, the main target of this study is the empirical investigation of this controversial theory. The main question of the research is raised, which is:

\section{Is there a relationship between liquidity, profitability, company size and corporation growth?}

Relevant data analysis and discussion will be used to answer this question in later research.

\subsection{The importance and value of the research}

Profitability can reflect a firm's overall health and higher profitability can even lead to more contented partners (Aderant, 2014). Subsequently, there are an increasing number of multinational enterprises inclined to invest capital in manufacturing beverages in the Chinese market (Mok, Dai and Yeung, 2002). As for the importance of liquidity, if a company has bad liquidity, it may not have sufficient ability to manage some risks such as financial crisis and it may risk losing large sums of capital when they sell illiquid assets during times of economic difficulty. Even worse, sometimes there aren't buyers at all (Marquit, 2012). Some conclusions about the correlations between profitability and liquidity have been made like Gitman (2003), Samiloglu and Demirgunes (2008) and Niresh (2012). The company size can be impacted by several factors; also, it an in turn, influence many operational activities. For example, small-size companies have a lower inventory level and can struggle to get discount from suppliers. In terms of corporation growth, if a company achieves growth, it can attract more customers, increase sales, expand products or services and take advantage of new opportunities, etc. (Scott \& Bruce, 1987) 
The particularity of my research is that more recent data is employed and choosing an industry of a nation that can reflect the industry's balance conditions about profitability, company size, corporation growth and liquidity of this nation. Hence problems in the process of dealing with the relationship between these variables may be exposed and other countries should learn from this and avoid similar problems. Furthermore, if beverage corporations can find the right balance between profitability, liquidity and other variables, their financial situation will be less vulnerable than others and top managers can make more comprehensive decisions for the company's operation (Sharma, 2015). Eventually, these companies may have enough competitive advantages to occupy a greater market share.

\subsection{Aim and objectives of the research}

The aim of this research is to examine the affiliation between profitability and liquidity and figure out what leads to this kind of correlation.

In order to achieve the aim, the following objectives were introduced:

- Determining whether there is a relationship between liquidity, profitability company size and corporation growth.

- $\quad$ Describing the nature of the relationship between liquidity, profitability company size and corporation growth.

- $\quad$ Evaluating the possible influence of the research results on the other areas.

These objectives will be referenced in the findings and discussion, as well as in the conclusion, in order to make the processes more clear and organised.

\subsection{The structure of this research}

The research has been sub-divided into seven sections, the first describing the background on the relationship between profitability, liquidity, company size and corporation growth and the importance of this research. Section two provides an evaluation of the literature, in which some methodologies are encompassed in the study such as desk research and later, regression analysis, examined in Section three. The fourth section represents research findings and results and in the fifth section, some discussions, related to research findings will be displayed such as the meaning of the research results and the factors which brought the study to its conclusions. The sixth section describes the limitations or disadvantages of this research and additionally, the conclusions and recommendations are provided in the final section.

\subsection{Literature Review}

After introducing the general structure of this research, this sector will list and analyse some previous research around the relationship between profitability, liquidity, company size and corporation growth.

\section{The relationship between profitability and liquidity}

The research proves that profitability and liquidity are both vital and contradictory aspects of corporate business, Ross (2000), Gitman (2003) and other scholars believe there is a dilemma in discovering the right balance between profitability and liquidity since their relationship is negative. Eljelly (2004) researched joint stock companies in Saudi Arabia and found there is a negative relationship between profitability and liquidity. Niresh (2012) proposed that a firm's profitability will be reduced if a firm increases liquidity or lays more emphasis on liquidity. The more firms rely on liquidity, the more idle funds they have and these idle funds do not attribute any profits to firms. Whereas, low liquidity indicates a firm has bad solvency, thus, its goodwill might be damaged and its credit profile impacted, owing to it.

Shah (2012) investigated the relationship between profitability and liquidity by analysing multivariate working capital. The outcome of this study illustrated that; profitability and liquidity were deemed opposite and imperative in business operation. Besides, organisations should pay increasing attention to the operating cycle period than the acid-test ratio and current ratio when they are regarded as a measure of liquidity. Anser and Malik (2013) share the same opinion with Shah (2012); they investigated the impact of the cash conversion cycle on the profitability of 
Pakistani manufacturing enterprises, during the time period of 2007 to 2011. The independent variable of the research was the cash conversion cycle and the dependent variables were the return on equity (ROE) and return on assets (ROA). They concluded that the relationship between the cash conversion cycle and a firm's profitability is negative. They also indicated that firms should reduce their cash conversion cycles since the Pakistani manufacturing industry will reap the benefits from it. Furthermore, Majeedetal (2013) summarised there is a contrary relationship between the cash conversion cycle and a firm's performance such as ROE, ROA and EBIT in Pakistan.

Several researchers however, do not agree that profitability and liquidity have a positive relationship. Usama (2012), in his study around the effect of profitability and liquidity on Pakistani food industry companies, between 2006 and 2010, found that liquidity and profitability are affected positively by management of working capital. Conversley, Rehman, et al., (2015) researched 99 listed companies, in order to study the relationship between profitability and liquidity of listed companies in the Saudi Stock Exchange. This research observed the current ratio along with the quick ratio, as indicators to measure the liquidity of firms. They summarised that there is indeed a positive relationship between ROA and current ratio. Moreover, the current study of Lartey, Antwi, and Boadi (2013) makes an earnest endeavour to investigate the relationship between liquidity and profitability of listed banks in Ghana. The profitability and liquidity of the banks are gauged by temporary investment ratio (TIR) and ROA respectively. The overall results revealed that there is a positive but simultaneously weak relationship between liquidity and profitability. Similarly, Vieira's study (2010), a sample of airline companies from 2005 and 2008 was researched and revealed that current ratio has a positive relationship with profitability. Besides, Bibi, N., and Amjad, S. (2017) came to the same conclusion as Vieira although these were both different from the main literature.

The relationship between corporation growth and company size

Jovanovic (1982) believed that corporation growth can alter with a company's history and size. He utilised a learning model to analyse company survival and found that corporation growth decreased when the learning efficiency of a firm declined when it enters the market; moreover he declared there is negative relationship between company growth and size. Evans (1987) made an all-sided empirical analysis through using a model which combines company size and age. He revealed similar results as Jovanovic. The company size and growth, however, have no link with each other and this conclusion was determined by Gibrat's law of proportionate effect (LPE).

\section{The relationship between company size and profitability}

For other relationships, Babalola (2013) found that both the company size and profitability have a positive relationship. He used a panel data set to analyse the influence of company size on the profitability of manufacturing firms listed in the Nigerian Stock Exchange between 2000 and 2009. ROA was employed as an indicator of profitability and sales, with total assets as indicators of company size. Abiodun (2013) and Ofuan and Izien (2016) arrived at the same conclusions as Babalola, yet few researchers found that the company size and profitability have a negative relationship like Amato and Burson (2007). Furthermore, Banchuenvijit (2012), in his study of the factors which influence Vietnamese companies' operating performance, discovered there is a negative correlation between total assets and profitability; on the other hand, a positive relationship was exposed between total sales and profitability.

\subsection{Research Methodology}

Based on the literature review in the final sector, 'construction of hypothesis', 'selection of sample and methodology' and 'methodology evaluation' will be described in this section to make preparation for later research.

\subsection{Construction of hypothesis}

The main question of this research is:

Is there any relationship between liquidity, profitability, company size and corporation growth?

To answer the question, I will build three hypotheses and they will be tested in this research: 
H1: The relationship between liquidity and profitability is negative.

Fixed assets are more profitable than current assets (Assaf Neto, 2003, p.22); hence a firm must give up more investment in fixed assets if it expects to maintain higher levels of current assets.

In fact, return on equity (ROE) is the most common indicator in measuring the profitability of a firm. This can be calculated by dividing net profit by the total shareholder equity. Nevertheless, the values for the equity of some companies in this research are very small hence ROA can resolve this issue. ROA can in fact measure the efficiency of managers and can generate operational profitability by utilising companies' assets. It cannot however, compare firm's performance with other investments (like bonds) as a companies' efficiency of generating profit from invested capital, fails to be gauged by ROA. For this study however, this indicator was able to be adopted because all of the companies of the sample, belonged to the same, (beverages) sector. As for liquidity, the current ratio and quick ratio can be used as indicators, whereas, the inventory usually accounts for a vast proportion of the current assets in the beverage industry and its stability is significant in measuring a company's liquidity; therefore inventory ought to be included. Still quick ratio does not consider inventory which current ratio considers does. Moreover, to reveal the warranty degree of current assets against current liabilities and to examine the security of short-term debt repayment, the current ratio is chosen to measure liquidity ratio.

\section{H2: There is a significant positive relationship between size and profitability of Chinese beverage firms.}

The size of firms may influence profitability and liquidity in different ways. The log of total assets and sales can be used to compute company size (Bibi and Amjad, 2017). Large companies are more easily able to access discounts from suppliers with relatively high inventory levels, owing to their large size. Nevertheless, smaller companies cannot get quantity discount because they do not have adequate inventories. On the other hand, large firms also have the ability to obtain favourable credit terms and these factors may cause them to have lower liquidity levels than smaller companies. Furthermore, large companies have a higher probability in getting their money back, in terms of receivables collection.

H3: There is a significant negative relationship between corporation growth and profitability of Chinese beverage firms.

The company growth refers to the development of a corporation's ability in a specific period of time. The main indicator is the growth rate of the principal business revenue. The high growth rate of revenue indicates a large demand for the company's products and therefore is the capacity for business expansion is boundless. Corporation managers often face the quandary between profitability and seeking growth. Companies are unable to respond to augmentations in external market conditions, in a timely manner, if they blindly pursue short-term profit-oriented performance. On the other hand, managers risk deficient performance and ultimately the corporation's survival, if they become obsessed with long term innovation.

\subsection{Selection of sample and methodology}

The Chinese beverage sector accounts for a significant proportion of the whole of the Chinese market, therefore research in this sector is conducive to be able to learn more about Chinese soft service. The beverage companies, viewed as a research sample, cover a diverse range of beverages, including coffee, wine, milk, tea, and other dairy product beverages. This can help to make research results more comprehensive. In addition, the financial data from an appropriate number of companies is easy to source but owing to time constraints, only 20 companies were selected yet this was sufficient to equip statistical analysis later on. As for the sample selection, this is a random sample selection which may generalise the results for other cases.

Data collection will entail desk research to gather major financial statistics, in order to obtain financial ratios. Hence annual reports from 2015 to 2017 were downloaded from companies' websites. Ratio analysis is indispensable for research as relevant indicators of variables can be calculated by using this method. Descriptive analysis is used to describe or summarise basic features of the data in a study quantitatively. It can also offer basic information about variables in a sample, whilst emphasising the potential correlation between variables. Correlation analysis is used to determine whether there is a relationship between these variables and regression analysis acts as a significant method in explaining the type and degree of correlation that exists. 


\subsection{Methodology Evaluation}

These research methodologies can ultimately assist in completing this research and inevitably, there are benefit and flaws to all methodologies. Desk research is useful in sourcing information, more often than not, such information can be inaccurate, however, all the financial data collected for this sample was sourced from companies' annual reports that follow International Financial Reporting Standards. Moreover, the annual reports of these companies are audited by reliable accounting firms and so there is no reason to doubt its authenticity. As is commonly recognised, financial statements are released periodically and so consequently, time differences exist in statements. The real prices would not be reflected in financial statements if inflation occurred between periods, hence ratio analysis is incorrect. No serious economic issues occurred during 2015-2017 in China and this factor can be neglected. As for descriptive analysis, it is helpful to illustrate, describe and summarise data in a more meaningful way so that data can be interpreted simply (laerd statistics, 2018). Regression analysis and correlation analysis are favourable in testing hypotheses and ensuring results are more reliable.

\subsection{Research Findings}

\subsection{Ratio Analysis}

Current ratio shows the ability of the business to recompense its short-term debts. The formula is current assets divided by current liabilities. The return on assets is an indicator of how much profit a firm can make from its assets and this can be computed by the net income dividing average total assets. Relevant indicators of profitability and liquidity can be calculated through ratio analysis. Relevant statistics are shown in the appendix.

\subsection{Description Analysis}

Description analysis can summarise specific features of data and provide basic information of variables. The results are summarised as below:

Table 2 Descriptive Statistics of Current Ratio (CR) and Return on Assets (ROA)

\begin{tabular}{|l|l|l|l|l|l|l|l|}
\hline & \multicolumn{3}{|l|}{ CR } & & & \multicolumn{2}{l|}{ ROA } \\
\hline & $\mathbf{2 0 1 5}$ & $\mathbf{2 0 1 6}$ & $\mathbf{2 0 1 7}$ & & $\mathbf{2 0 1 5}$ & $\mathbf{2 0 1 6}$ & $\mathbf{2 0 1 7}$ \\
\hline Average & 2.02 & 1.94 & 1.94 & & 0.09 & 0.07 & 0.10 \\
\hline Standard Deviation & 1.29 & 1.201 & 1.23 & & 0.08 & 0.1 & 0.09 \\
\hline Median & 1.64 & 1.6 & 1.4 & & 0.08 & 0.07 & 0.09 \\
\hline Maximum & 5.6 & 5.27 & 5.67 & & 0.31 & 0.29 & 0.38 \\
\hline Minimum & 0.61 & 0.35 & 0.71 & & -0.04 & -0.16 & -0.05 \\
\hline
\end{tabular}

Table 2 represents the results of descriptive statistics for 20 beverage companies, over the period of three years between 2015 and 2017. Return on Assets is regarded as variable for measuring a company's profitability. The mean, standard deviation and median were on the same level from 2015 to 2017 and they are not higher than 0.1 , which shows most companies have a poor ability in managing their balance sheet to generate profits. The highest profitability indicator was only 0.38 and the worst was -0.16 . Moreover, the minimum value was negative for three consecutive years that signifies there are some companies that performed extremely poorly during the three years and subsequently these had a negative return.

The average current ratios were proximal to 2 in the three years, meaning a firm has enough capacity like current assets to meet its short-term obligations. The median remained approximately 1.5, which is good although it declined gradually from 1.64 to 1.4. A similar decrease occurred for the standard deviation, which went by 0.06 . From the median and standard deviations we can see most companies can manage the relationship between their current assets and current liability well and goods remained at an admirable level during the three years. The difference between maximum and minimum value however is vast and the gap being nearly 5 indicated some firms may not use their assets efficiently, hereby some firms have a higher risk of distress or default. 
Table 3 Descriptive Statistics of total assets and sales

\begin{tabular}{|c|c|c|c|c|c|c|}
\hline & & \multicolumn{2}{|l|}{ Total Assets } & & \multicolumn{2}{|l|}{ Sales } \\
\hline & 2015 & 2016 & 2017 & 2015 & 2016 & 2017 \\
\hline Mean & 1.63374 & 1.660163653 & 1.716766 & 1.53327 & 1.567526 & 1.612785394 \\
\hline $\begin{array}{l}\text { Standard } \\
\text { Deviation }\end{array}$ & $\begin{array}{l}0.79303 \\
5\end{array}$ & 0.804628423 & 0.779734 & $\begin{array}{l}0.79152 \\
6\end{array}$ & 0.787154 & 0.760050489 \\
\hline Median & $\begin{array}{l}1.75252 \\
8\end{array}$ & 1.820173109 & 1.832032 & 1.511027 & 1.525649 & 1.5443883 \\
\hline Maximum & $\begin{array}{l}2.72054 \\
8\end{array}$ & 2.793608809 & 2.850787 & $\begin{array}{l}2.78074 \\
9\end{array}$ & 2.782537 & 2.832879182 \\
\hline Minimum & -0.18709 & -0.346787486 & -0.05552 & -0.18709 & -0.20066 & 0.017033339 \\
\hline
\end{tabular}

The $\log$ of total assets and sales is used as a proxy variable for measuring the size of firms. The means of these two indicators grew consistently in three years; this means the sizes of Chinese beverage companies are not small and they were able to achieve consistent growth. The standard deviation declined, meaning the difference between firms in the sample became smaller. The maximum and minimum values were unstable and the biggest difference between them appeared in 2016. The change of median shows the same trend as mean.

Table4 Descriptive Statistics of Growth rate of revenue

\begin{tabular}{|l|l|l|l|}
\hline & \multicolumn{3}{|l|}{ Growth rate of revenue } \\
\hline & $\mathbf{2 0 1 5}$ & $\mathbf{2 0 1 6}$ & $\mathbf{2 0 1 7}$ \\
\hline Average & 0.082505 & 0.09307 & 0.091535 \\
\hline Standard Deviation & 0.220332432 & 0.159143001 & 0.192273422 \\
\hline Median & 0.03125 & 0.05505 & 0.06115 \\
\hline Maximum & 0.8026 & 0.487 & 0.6522 \\
\hline Minimum & -0.1602 & -0.0812 & -0.1917 \\
\hline
\end{tabular}

Growth rate of revenue (GRR) is a tool utilised for measuring the corporation growth. The mean value of the growth rate of revenue was not high, nearly 0.08; it indicates the firms grew gradually from 2015 to 2017 . Yet the standard deviation was at least 0.15 that indicates the growth speed of each company is very different. The median was low, although it increased from 0.03 in 2015 to 0.06 in 2017. For the maximum and minimum values, they both declined over the three years; what is worth observing is the maximum value could maintain a similar and positive level but the minimum value always shows a negative result. It suggested that a small co-hort of companies were in fact in a grave stage of development.

\subsection{Correlation Results}

Table 5 Correlation statistics in Year 2015

\begin{tabular}{|l|l|l|l|l|l|}
\hline & CR & TA & Sales & GRR & ROA \\
\hline CR & 1 & & & & \\
\hline TA & 0.131786 & 1 & & & \\
\hline Sales & -0.00861 & 0.968074 & 1 & & \\
\hline GRR & -0.14503 & -0.05781 & -0.12117 & 1 & \\
\hline ROA & 0.047561 & -0.0482 & 0.042875 & 0.069861 & 1 \\
\hline
\end{tabular}

From Table 5, the relationship between ROA and CR, TA, Sales and GRR are all very weak; in other words, there is no relationship between profitability and liquidity, company size and corporation growth in 2015 . 
Table 6 Correlation statistics in Year 2016

\begin{tabular}{|l|l|l|l|l|l|}
\hline & CR & TA & GRR & Sales & ROA \\
\hline CR & 1 & & & & \\
\hline TA & 0.081254 & 1 & & & \\
\hline GRR & -0.10528 & -0.10108 & 1 & & \\
\hline Sales & -0.08101 & 0.965642 & -0.14104 & 1 & \\
\hline ROA & 0.437792 & 0.093142 & 0.113626 & 0.072528 & 1 \\
\hline
\end{tabular}

The current ratio has a positive relationship with a return on assets that implies the profitability of a firm will grow, if the liquidity increases in 2016. Similarly, the growth rate of revenue has a weak positive relation with the profitability of the company. It indicates that the corporation growth is associated with an increase in the performance of a firm, although it is not significant. There is an insignificant positive correlation between the log of total assets, sales and profitability.

Table 7 Correlation statistic in Year 2017

\begin{tabular}{|l|l|l|l|l|l|}
\hline & CR & TA & Sales & GRR & ROA \\
\hline CR & 1 & & & & \\
\hline TA & 0.071864 & 1 & & & \\
\hline Sales & -0.09697 & 0.9693 & 1 & & \\
\hline GRR & -0.36406 & -0.26468 & -0.18988 & 1 & \\
\hline ROA & -0.13148 & 0.233456 & 0.325393 & 0.230941 & 1 \\
\hline
\end{tabular}

In 2017, there is an insignificant and negative correlation between current ratio and a return on assets. Except that, the results show that the log of total assets and sales have a significant positive relationship; it implies that the firm will be profitable if its size is bigger. As for the revenue growth rate, it has a weak positive relationship with the return on assets. This result indicates the firm will possess higher profitability if the speed of corporation growth becomes higher.

\subsection{Regression Analysis}

From correlation analysis, total assets and sales have a significant and positive relationship. ROA is regarded as a dependent variable and CR, TA, Sales and GRR are independent variables. Independent variables have a significant relationship with each other that will cause multicollinearity; then the regression analysis results will be significantly impacted. Consequently, the log of total assets will be used as an indicator of company size in the regression analysis. This can certainly make research results more accurate.

The basic regression equation of study is as follows:

\section{ROA $=\beta 0+\beta 1 C R+\beta 2 T A+\beta 3 S a l e s+\beta 4 G R R+e$}

Table 8 Year 2015

\begin{tabular}{lrrrl}
\hline & Coefficients & Std. Error & t Stat & P-value \\
\hline CR & 0.003956956 & 0.015291 & 0.258781 & 0.799104 \\
TA & -0.005138457 & 0.024605 & -0.20884 & 0.837211 \\
GRR & 0.026932889 & 0.088726 & 0.303551 & 0.765381 \\
\hline
\end{tabular}

Multiple R

0.104768541

R Square

0.010976447

Adjusted R Square

$-0.174465469$

Significance F
0.980446354

The significant $\mathrm{F}$ is used to reflect the linear significance of all independent variables to the dependent variable. $\mathrm{P}$-value refers to the linear significance of every variable to the dependent variable. Whereas the significant $\mathrm{F}$ and 
P-value is too high which are both higher than 0.05 that means the liquidity, company size and corporation growth have no significant correlation with profitability in 2015. There is however, an insignificant positive relationship between corporation growth and profitability from the coefficients.

Table 9 Year 2016

\begin{tabular}{lclrr}
\hline & Coefficients & Std. Error & \multicolumn{1}{c}{ t Stat } & \multicolumn{1}{c}{ P-value } \\
\hline CR & 0.036491986 & 0.018037196 & 2.023152 & 0.0601 \\
TA & 0.008926459 & 0.026923417 & 0.33155 & 0.74453 \\
GRR & 0.103209751 & 0.136433071 & 0.756486 & 0.46035 \\
\hline
\end{tabular}

$\begin{array}{ll}\text { Multiple R } & 0.472013001 \\ \text { R Square } & 0.222796273 \\ \text { Adjusted R Square } & 0.077070574 \\ \text { Significance F } & 0.245404686\end{array}$

In 2016, P-value of CR is smallest, thus implying the current ratio has a weak and positive relationship with return on assets. It implies that company's enhancement in managing short term obligations has a positive effect on its profitability. From Table 9, there is an insignificant positive relationship between the growth rate of revenue and the return on assets. Moreover, results show that $1 \%$ changes in growth rate of revenue leads to $1.03 \%$ unit change in companies' profitability. The coefficient of the log of total assets is too small and it can be neglected; hence the $\log$ of total assets has no relationship with the return on assets.

Table 10 in Year 2017

\begin{tabular}{lrrrl}
\hline & \multicolumn{1}{c}{ Coefficients } & \multicolumn{1}{c}{ Std. Error } & \multicolumn{1}{c}{ t Stat } & P-value \\
\hline CR & -0.003428303 & 0.01857316 & -0.18458 & 0.855875 \\
TA & 0.037415587 & 0.028374998 & 1.318611 & 0.205863 \\
GRR & 0.14319615 & 0.123229382 & 1.162029 & 0.262265 \\
\hline
\end{tabular}

$\begin{array}{lr}\text { Multiple R } & 0.385307199 \\ \text { R Square } & 0.148461638 \\ \text { Adjusted R Square } & -0.011201805 \\ \text { Significance F } & 0.44902866\end{array}$

Table 10 shows that $\mathrm{R}$ square of model is 0.14 for the return on assets, this infers explanatory variables of models, only depicting a $14 \%$ variation. The results imply that current ratio has no relationship with the return on assets since its p-value is too high. Additionally, the $\log$ of total assets and growth rate of return have an insignificant positive correlation with the return on assets. Overall, the relevant fitting degree is bad.

\subsection{Discussions}

Based on the research in the previous section, this section will discuss the results of the findings.

\subsection{Hypothesis 1}

The relationship between liquidity and profitability is negative.

This hypothesis was completely rejected by research findings. The correlation between the two variables was weak and positive in 2016 and there was no relationship between them in 2015 and 2017. This result contradicts some of the studied literature. Anser and Malik (2013) can support this hypothesis as they found a negative correlation for the indicators of liquidity and profitability when they researched firms in the manufacturing sector of Pakistan. Marques e Braga (1995) and Pimentel et al. (2005) obtained these negative correlation results for different samples as well. Yet the industry and country that this research chose may be different from above researches; it may lead 
to different results. The results show that liquidity has little or no effect on profitability. The positive correlation may be explained by the fact that market requirements increased in 2016 and the operation of the beverage sector demands a higher level of current expenses (fresh materials of purchase and storage, etc.) Thus a higher level of working capital may decrease the costs; thus achieving higher profits.

\subsection{Hypothesis 2}

There is a significant positive relationship between the size and profitability of Chinese beverage firms.

This hypothesis was also refuted. The research findings represent that there is an insignificant positive relationship between size and profitability, despite there being no relationship between them. The research of Uwuigbe et al. (2016) can support this and they discovered that there is no relationship between the size and profitability of some corporate firms. One of the possible reasons for the positive correlation is that big firms are more efficient than small firms as they fully utilise the scale of the economy.

\subsection{Hypothesis 3}

There is a significant negative relationship between corporation growth and the profitability of Chinese beverage firms.

This hypothesis was rejected by research findings. Across all of the years analysed, the corporation growth had an insignificant positive relationship with profitability. This result is a stark contrast from some research and this was negated by the growth maximisation hypothesis. Akihiko and Dongun (2011) can support this hypothesis; they included 1633 Japanese manufacturing firms as a sample and found that there is indeed an exchange between profitability and growth. The study indicates that excessive current growth is detrimental to future profit. The possible reason for an insignificant positive relationship is that Chinese beverage companies' growth primarily depends on other factors rather than simply profit.

\subsection{Limitations}

This section will catalogue some of the limitations of this research and will explore how to minimise these. This research is based on a small sample size and notably the particularity may appear when only 20 beverage companies are used to represent the Chinese beverage industry. Yet it does contain as many beverage brands as possible and it is a random sample selection; therefore the probability of appearing particularity can be reduced to some extent. In future research, the sample size will be bigger to diminish any adverse impact upon the analytical procedure. In terms of the reading materials, this research introduced some unique relationships between profitability, liquidity, company size and corporation growth of previous research; nevertheless, other relationships were not depicted which could be detrimental for the reader's perception of previous research. To reduce this, as many relationships as possible were revealed in the 'Literature Review' but looking to the future. more, relevant books, journals, and newspapers ought to be read in the future research.

As for the variables and indicators chosen, the amounts of variables are small comparatively, which may affect the validity of the research. Detailed analysis of each variable, however, reduces the impact of this limitation; consequently more variables should be used in future research. Similarly, every variable has only one or two indicators and so may not reflect the alteration in every variable. The most representative indicators were chosen, to reduce the effect of limitation but an increasing number of variables and indicators are required in similar research. Analytical methods may be biased toward one direction which does not reflect the nature of the research title. For instance, correlation analysis only shows the relationship between variables yet it cannot explain the cause-and-effect relationship between variables. Multiple analysis methods were used as corresponding remedial measures and hereby research results were more precise (description analysis, correlation analysis and regression analysis). These can be used to locate and explain the research topic. The more comprehensive methods of analysis are used to overcome this limitation. 


\subsection{Conclusion and Recommendation}

This section will summarise research outcomes and highlight some additional research values of this dissertation. This study experientially examines the affiliation between liquidity, company size, corporation growth and profitability, within a sample of 20 companies from the beverage sector in China. All hypotheses were in fact rejected and the study found liquidity has a weak positive relationship with profitability. Moreover, there is an insignificant positive relationship between company size, corporation growth and profitability, despite there being no relationship between them in some instances. This means that policy aimed at enhancing the profitability ought not to be directed at increasing liquidity, corporation growth and size as the policy will have little or no influence on the profitability. Companies will waste much time and capital on meaningless elements that may hamper corporation growth. Therefore the policy recommendation is such that companies should focus increased attention on other factors, whilst determining the key success factors for their businesses. For instance, sales and expense controls should be considered as two success factors.

The research results are not applicable for all aspects and so can only be regarded as a reference. From another perspective, the results can assist some readers who do not have professional knowledge to learn related knowledge. It can also provide a reference point for some professionals. To be precise, this research can be useful for individuals concerned with marketing, law, strategic management or other similar aspects. If firms are very clear about the relationship and know how to manage it, they must know what kind of strategy can help them achieve maximum profit. For instance if they have a good balance between these two indicators, they may be able to maintain long term business operations, even during difficult times. Hereby, corporations have a reduced likelihood of facing risks around breaking the law. Moreover, stakeholders are more likely to invest more in firms as they believe firms have a more efficient operational ability and higher reliability. Thus, firms are able to attain long term investment from shareholders as well as an increasing number of loans from banks or other firms. Additionally, the regression analysis results encompass constants that can make results more precise, therefore allowing the research results to be more realistic. In the future, research will be directed towards cash holdings and firm value as these two factors have close connections with liquidity and profitability separately. Furthermore, this research direction will reveal more details about factors affecting corporate profitability and liquidity and additional significant information like the impact of cash holding on firm.

\section{Reference}

1. Abiodun, B. Y. (2013). The Effect of Firm Size on Firms Profitability in Nigeria. Journal of Economics and Sustainable Development, 4(5), 90-94.

2. Aderant. (2014). Why is "Profitability" So Important? [Online] Available from: https://www.aderant.com/think-tank/profitability-important/ [Accessed: 2019 ].

3. Amato, L. H. and Burson, T. E. (2007), "The effects of firm size on profit rates in the financial services", Journal of Economics and Economic Education Research, Vol. 8, Issue 1, pp. 67 - 81.

4. Amit, K., Mallik, D. S., \& Debdas, R. (2005). Working Capital and Profitability: A Study on Their Relationship with Reference to Selected Companies in Indian Pharmaceutical Industry. GITAM Journal of Management, 3(2), 51 - 62 .

5. Anser, R., \& Malik, Q. A. (2013). Cash Conversion Cycle and Firms' Profitability-A Study of Listed Manufacturing Companies of Pakistan. Journal of Business and Management, 8(2), 82-87.

6. Assaf Neto, A. (2003). Finanças Corporativas e Valor. São Paulo: Atlas.

7. Averkamp, H. (2004) What is liquidity? [Online] Available from: https://www.accountingcoach.com/blog/what-is-liquidity [Accessed: 2019 ].

8. Babalola, Y A (2013) The Effect of Firm Size on Firms Profitability in Nigeria, Journal of Economics and Sustainable Development, ISSN 2222-1700 (Paper) ISSN 2222-2855 (Online)Vol.4, No.5

9. Banchuenvijit, W. (2012), "Determinants of Firm Performance of Vietnam Listed Companies", Academic and 
Business Research Instttute. http://aabri.com/SA12Manuscripts/SA12078.pdf

10. Bibi, N., \& Amjad, S. (2017). The relationship between liquidity and firms' profitability: A case study of Karachi Stock Exchange. Asian Journal of Finance \& Accounting, 9(1), 54-67.

11. Bibi, N., \& Amjad, S. (2017). The relationship between liquidity and firms' profitability: A case study of Karachi Stock Exchange. Asian Journal of Finance \& Accounting, 9(1), 54-67.

12. Doğan M (2013) Does Firm Size Affect The Firm Profitability? Evidence from Turkey, Research Journal of Finance and Accounting ISSN 2222-1697 (Paper) ISSN 2222-2847 (Online) Vol.4, No.4.

13. Eljelly, A. (2004). Liquidity - profitability tradeoff: an empirical investigation in an emerging market. IJCM, 14 (2), 48-61.

14. Evans, D. S. (1987). The relationship between firm growth, size, and age: Estimates for 100 manufacturing industries. The journal of industrial economics, 567-581.

15. Gitman, L. (1989). Basic Managerial Finance. 2nd edition. New York: Harper \& Row.

16. Gitman, L. J. 2003. Principals of managerial finance. New York: Addison Wesley.

17. Jovanovic, Boyan, 1982. "Selection and the Evolution of Industry," Econometrica, Econometric Society, vol. 50(3), pages 649-670, May.

18. Laerd statistics. (2018). Descriptive and Inferential Statistics. [Online] Available from: https://statistics.laerd.com/statistical-guides/descriptive-inferential-statistics.php [Accessed: 2019].

19. Marques, J. A. C., \& Braga, R. (1995) Análise dinâmica do capital de giro: o Modelo Fleuriet. RAE - Revista de Administração de Empresas. 35 (3) 49-63.

20. Marquit, M. (2012) Investing Basics: Why Liquidity Matters. [Online] Available from: https://money.usnews.com/money/blogs/the-smarter-mutual-fund-investor/2012/12/03/investing-basicswhy-liquidity-matters [Accessed: 2019 ].

21. Mok, V., Dai, X. and Yeung, G., 2002. An Internalization Approach To Joint Ventures: The Case Of CocaCola In China. [ebook] Asia Pacific Business Review. Available at: $<$ http://sro.sussex.ac.uk/id/eprint/124/1/Coca_Cola.pdf> [Accessed 27 June 2018].

22. Ofuan. J. Ilaboya1 \& Izien. F. Ohiokha,(2016), Firm Age, Size and Profitability Dynamics: A Test of Learning by Doing and Structural Inertia Hypotheses, Business and Management Research. Vol. 5, No. 1.

23. Perobelli, F. F. C., Pereira, J. F. \& David, M. V. (2006). Relação Liquidez-Retorno: Existiria também uma "Estrutura de Liquidez" Ideal para cada Perfil de Empresa? EnAMPAD.1-16. http://www.anpad.org.br/enanpad/2006/dwn/enanpad2006-ficb-2510.pdf

24. Pimentel, R. C., Braga, R., \& Casa Nova, S. P. C. (2005). Interação entre rentabilidade e liquidez: um estudo exploratório. Revista de Contabilidade do Mestrado em Ciencias Contábeis da UERJ, Rio de Janeiro - 10 (2), PP. 83-98.

25. Ross, S. A., Westerfield, R. W., \& Jordan, B. D. (2000). Fundamentals of Corporate Finance. McGraw-Hill.

26. Scott, M., \& Bruce, R. (1987). Five stages of growth in small business. Long range planning, 20(3), 45-52.

27. Sharma,P. (2014).Liquidity vs. Profitability [Online] Available from: https://www.linkedin.com/pulse/liquidity-vs-profitability-pankaj-sharma [Accessed: 2019].

28. Sritharan, Vinasithamby (2015), Does firm size influence on firm's Profitability? Evidence from listed firms of Sri Lankan Hotels and Travels sector, Research Journal of Finance and Accounting, ISSN 2222-1697 (Paper) ISSN 2222-2847 (Online) Vol.6, No.6. 
29. Uwuigbe O, Uwuigbe U adeyemo A K land Ogunbanjo D (2016) Influence of corporate attribute on business success in Nigeria , international business management 10(13): 2564-2569.

30. Uyar, A. (2009). The relationship of cash conversion cycle with firm size and profitability: an empirical investigation in Turkey. International Research Journal of Finance and Economics, 24(2), 186-193.

31. Vieira, R. (2010). The relationship between liquidity and profitability: An exploratory study of airline companies between 2005 and 2008.

Notes

2015 year

\begin{tabular}{|c|c|c|c|c|}
\hline $\begin{array}{l}\text { Current } \\
\text { Ratio }\end{array}$ & Assets & GRR & ROA & Sales \\
\hline 0.61 & -0.18709 & 0.0317 & 0.11 & -0.18709 \\
\hline 1.62 & 0.752048 & 0.0086 & 0.07 & 0.924279 \\
\hline 2.03 & 0.447158 & -0.028 & 0.19 & 0.555094 \\
\hline 1.07 & 2.188844 & -0.0618 & 0.04 & 2.287197 \\
\hline 1.2 & 1.64875 & 0.4909 & 0.06 & 1.2266 \\
\hline 1.09 & 2.598035 & 0.1094 & 0.12 & 2.780749 \\
\hline 1.4 & 2.704605 & 0.1088 & 0.05 & 2.690435 \\
\hline 1.66 & 1.447623 & 0.1075 & 0.03 & 1.368473 \\
\hline 1.08 & 1.90477 & -0.1288 & 0.008 & 1.589726 \\
\hline 3.45 & 2.119981 & 0.205 & 0.12 & 1.838849 \\
\hline 5.6 & 2.720548 & 0.0308 & 0.13 & 2.335638 \\
\hline 1.22 & 2.45486 & -0.0487 & 0.06 & 2.441459 \\
\hline 1.33 & 2.261096 & -0.0715 & 0.03 & 2.098228 \\
\hline 2.02 & 1.856306 & 0.1296 & 0.1 & 1.720407 \\
\hline 1.59 & 1.031812 & 0.8026 & 0.07 & 0.770115 \\
\hline 1.76 & 1.224533 & -0.0675 & 0.12 & 1.29048 \\
\hline 2.15 & 1.97211 & 0.1035 & 0.31 & 1.959852 \\
\hline 5.03 & 1.025306 & -0.1602 & -0.04 & 0.528917 \\
\hline 2.46 & 1.490801 & 0.0013 & 0.21 & 1.432328 \\
\hline 2.14 & 1.012837 & 0.0869 & 0.09 & 1.01368 \\
\hline
\end{tabular}




\begin{tabular}{|c|c|c|c|c|}
\hline \multicolumn{5}{|c|}{2016 year } \\
\hline CR & TA & GRR & Sales & ROA \\
\hline 0.35 & -0.34679 & -0.028 & -0.20066 & -0.12 \\
\hline 1.79 & 0.771587 & 0.0824 & 0.92993 & 0.07 \\
\hline 2.71 & $\mathbf{0 . 5 5 7 5 0 7}$ & 0.1548 & 0.658965 & 0.16 \\
\hline 1.05 & 2.206286 & 0.043 & 2.305502 & 0.04 \\
\hline 1.18 & 1.71617 & 0.4518 & 1.388456 & 0.07 \\
\hline 1.35 & 2.593972 & 0.0075 & 2.782537 & 0.14 \\
\hline 1.3 & 2.691294 & 0.0041 & 2.730613 & -0.16 \\
\hline 1.56 & 1.505693 & 0.0439 & 1.387034 & 0.04 \\
\hline 0.91 & 1.924176 & 0.1481 & 1.649724 & 0.008 \\
\hline 3.93 & 2.135896 & 0.2034 & 1.919287 & 0.14 \\
\hline 3.98 & 2.793609 & 0.1332 & 2.389945 & 0.12 \\
\hline 1.23 & 2.478235 & -0.0553 & 2.41674 & 0.04 \\
\hline 1.33 & 2.261382 & -0.077 & 2.063446 & 0.02 \\
\hline 1.79 & 1.941313 & 0.1454 & 1.77938 & 0.1 \\
\hline 1.26 & 1.065206 & 0.487 & 0.942008 & $\mathbf{0 . 0 7}$ \\
\hline 1.71 & 1.33626 & 0.2244 & 1.378398 & 0.14 \\
\hline 2.21 & 1.989494 & -0.0238 & 1.949683 & 0.29 \\
\hline 5.27 & $\mathbf{1 . 0 7 1 5 1 4}$ & -0.0812 & 0.436163 & 0.08 \\
\hline 2.35 & 1.449015 & -0.0685 & 1.401573 & 0.16 \\
\hline 1.64 & 1.061452 & 0.0662 & 1.041787 & 0.09 \\
\hline
\end{tabular}

2017 year

\begin{tabular}{|c|c|c|c|c|}
\hline CR & TA & Sales & GRR & ROA \\
\hline 0.71 & -0.05552 & 0.017033 & 0.6522 & 0.14 \\
\hline 1.49 & 0.764176 & 0.980003 & 0.0498 & 0.08 \\
\hline 1.37 & 0.663701 & 0.735599 & 0.0349 & 0.16 \\
\hline 0.87 & 2.218509 & 2.335899 & 0.0725 & 0.05 \\
\hline 1.2 & 1.74935 & 1.374198 & -0.0326 & 0.01 \\
\hline 1.25 & 2.692847 & 2.832879 & 0.12 & 0.13 \\
\hline 1.15 & 2.764468 & 2.779279 & 0.1229 & 0.38 \\
\hline 1.83 & 1.460447 & 1.403978 & 0.0396 & 0.05 \\
\hline 0.91 & 1.914713 & 1.667173 & 0.041 & 0.009 \\
\hline 3.27 & 2.295699 & 2.016824 & 0.205 & 0.15 \\
\hline 3.96 & 2.850787 & 2.47982 & 0.2299 & 0.15 \\
\hline 1.35 & 2.491011 & 2.419576 & 0.0065 & 0.04 \\
\hline 1.43 & 2.257631 & 2.049063 & -0.0326 & 0.009 \\
\hline 1.95 & 2.006594 & 1.843108 & 0.1581 & 0.12 \\
\hline 1.26 & 1.155032 & 1.093422 & 0.4171 & 0.08 \\
\hline 2.45 & 1.448397 & 1.421604 & 0.1049 & 0.1 \\
\hline 2.43 & 2.04883 & 1.888797 & -0.1303 & 0.22 \\
\hline 5.67 & 1.029384 & 0.499687 & -0.1917 & -0.05 \\
\hline 2.99 & 1.453777 & 1.324694 & -0.1623 & 0.14 \\
\hline 1.19 & 1.125481 & 1.093071 & 0.1258 & 0.09 \\
\hline
\end{tabular}

